\title{
Surfaces
}

\section{THE EMPIRE BUILDER: WAR AND THE SUBJECT OF THE HUMANITIES}

\section{Jenny Horne et Jonathan Kahana}

Volume 3, 1993

URI : https://id.erudit.org/iderudit/1065096ar

DOI : https://doi.org/10.7202/1065096ar

Aller au sommaire du numéro

Éditeur(s)

Les Presses de l’Université de Montréal

ISSN

1188-2492 (imprimé)

1200-5320 (numérique)

Découvrir la revue

Citer cet article

Horne, J. \& Kahana, J. (1993). THE EMPIRE BUILDER: WAR AND THE SUBJECT OF THE HUMANITIES. Surfaces, 3. https://doi.org/10.7202/1065096ar
Résumé de l'article

Dans De la guerre, traité politique qu'écrit Carl von Clausewitz en 1832, c'est un humaniste qui occupe la fonction de général d'armée. Or, on sait que cette figure traditionnelle du savoir qu'est l'humaniste n'acquiert un statut discursif officiel qu'avec la création de la discipline des Humanités, aux États-Unis, après la première guerre mondiale. Puisant chez Clausewitz et dans la rhétorique qui entoure la récente " crise des Humanités ", nous cherchons à savoir « où sont en fait situées nos institutions militaires?".

Pour en montrer l'interdépendance, nous reformulons les histoires de la guerre moderne et de l'érudition humaniste dans des termes réciproques. Nous montrons ainsi comment les idéaux humanistes (débat rationnel, érudition et appréciation de la culture, culte de la beauté et de la vérité) sont liés à l'épistémologie de la guerre. Un exemple tactique de ce conflit perpétuel est considéré : le récent abolissement du département des humanités à l’Université du Minnesota.
Copyright $(\subset)$ Jenny Horne et Jonathan Kahana, 1993

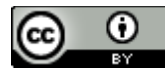

Ce document est protégé par la loi sur le droit d'auteur. L'utilisation des services d'Érudit (y compris la reproduction) est assujettie à sa politique d'utilisation que vous pouvez consulter en ligne.

https://apropos.erudit.org/fr/usagers/politique-dutilisation/ 


\title{
THE EMPIRE BUILDER:
}

\section{WAR AND THE SUBJECT OF THE HUMANITIES}

\author{
Jenny Horne \& Jonathan Kahana
}

\begin{abstract}
In Carl von Clausewitz's 1832 political treatise On War, the military general is given the form of the humanist scholar. But it isn't until the establishment in the United States of the discipline of the Humanities, between the world wars, that this traditional figure of knowledge is given official discursive status. Using Clausewitz and the rhetoric of the most recent "crisis in the Humanities", we pose the question, "where in fact are our military institutions located?".

In order to show the interdependence of these two apparently discrete histories, one would have to redefine modern warfare and humanist scholarship in terms of each other. To this end, we frame the humanist ideals of rational debate, erudition and cultural appreciation, and the production of truth and beauty, as historically linked to the epistemology of war. We address a recent tactical example of this perpetual war -- the closing of the humanities department at the University of Minnesota.
\end{abstract}

\section{RÉSUMÉ}

Dans De la guerre, traité politique qu'écrit Carl von Clausewitz en 1832, c'est un humaniste qui occupe la fonction de général d'armée. Or, on sait 
que cette figure traditionnelle du savoir qu'est l'humaniste n'acquiert un statut discursif officiel qu'avec la création de la discipline des Humanités, aux Etats-Unis, après la première guerre mondiale. Puisant chez Clausewitz et dans la rhétorique qui entoure la récente $<<$ crise des Humanités $>>$, nous cherchons à savoir <<où sont en fait situées nos institutions militaires? $>$.

Pour en montrer l'interdépendance, nous reformulons les histoires de la guerre moderne et de l'érudition humaniste dans des termes réciproques. Nous montrons ainsi comment les idéaux humanistes (débat rationnel, érudition et appréciation de la culture, culte de la beauté et de la vérité) sont liés à l'épistémologie de la guerre. Un exemple tactique de ce conflit perpétuel est considéré: le récent abolissement du département des humanités à l'Université du Minnesota.

In his essay "Railway Navigation and Incarceration," Michel de Certeau likens the interior of a train car to "the immobility of an order."[1] One is trapped within the rigidity of a compartmentalization, under a command, with nothing to do but cast a disinterested or occasionally surprised glance at the world as it passes. Vision fixes the relationship between the inside and the outside. Between these two mute and frozen spaces are the window and the rail: the window allows us to see, the rail allows us to move through. These are complementary modes of separation, de Certeau tells us: the first creates distance and objectivity, the second inscribes "the injunction to pass on; it is an order written in a single but endless line: go, leave, this is not your country..." (112).

But on the Empire Builder, the train from Chicago to Seattle, the injunction is exactly the opposite: this is your country, take it all in. A certain practice of reading would obscure the relationship in the name of this route between vision, nation, and the spirit of venture capitalism. The oversight of common sense would not see the irony: after all, we might want to ask, how is a domestic route a builder of an empire? As we hope to demonstrate here, this train itself follows in the tracks of two nineteenth century phenomena which embody the metaphorics of vision and the legacy of history: the first is the military general, and the second is the humanist subject. Using Clausewitz and the rhetoric of the most recent 'crisis in the humanities' we will pose the question, "where, in fact, are our military institutions located?" and address a recent, tactical example of this perpetual war -- the closing of the Humanities Department at the University of Minnesota.

De Certeau calls the train "a tireless shifter," (113) because it creates an ahistorical passage between observers and objects, settling its constituents 
within "a gridwork of technocratic discipline, a mute rationalization of laissez-faire individualism".(113). Similarly, the army and the liberal arts place their subjects under the silent regime of internal and external surveillance. At the head of the empirical mechanism of knowledge stands a revolutionary perspective on the history of that production. After the great wars of empire at the beginning of the nineteenth century, after the dominance of the Napoleonic general, the name of this perspective is the knowing and self-knowing subject.

Recent debate over the so-called "crisis in the humanities" has mapped the intellectual history of this discipline as a proud march of civilization. In this conservative scenario, the seamless progression is threatened by dissent and controversy. A genealogy of the disciplines since the late nineteenth century would find, however, that the humanist ideals of dialogue, reflection, imagination, and insight, originate and re-originate in conditions of conflict and uncertainty. The effect of tradition is created by the tireless shifter of metaphor, an optical illusion which is so important to the knowledge of war. "War," wrote Carl von Clausewitz in his 1832 treatise On War, "belongs not to the province of Arts and Sciences, but to the province of social life ... It would be better, instead of comparing it with any Art, to liken it to business competition...and it is still more like State policy, which again on its part, may be looked upon as a kind of business competition on a great scale. Besides, State policy is the womb in which War is developed, in which its outlines lie hidden in a rudimentary state, like the qualities of living creatures in their germs."[2] Shunting between the domains of war and the humanities, what the tireless shifting of metaphor maps in our analysis is the space of national empire.

Towards the end of On War, Clausewitz asks "Is not war merely another kind of writing and language for political thoughts?" His answer indicates that the effect of the book thus far has been to install war as the logic of a social order which will discipline itself with literacy. War can be likened to writing insofar as it operates by rules and conventions; but at the same time the logic of war is imposed on it from without. This circulation of a metaphor -war is a form of writing, writing is a form of politics -- is accomplished by the initial linking of war and politics or policy, for which this text is renowned: war is a continuation of policy by other means. This line has become a commonplace, meant to express the fragile balance of peace in the relations between national empires. When the terms war and policy are related in this way, however, the equation has the effect of disengaging these social forms from each other, as if the rise of international diplomacy simply exchanges war for politics.

When Foucault proposes the reversal of the Clausewitzian dictum, he is acknowledging the need to reconsider the discrete ontologies of war and 
politics. "One would then confront the original hypothesis, according to which power is essentially repression, with a second hypothesis to the effect that power is war, a war continued by other means."[3] Foucault says that political power must be understood to rely on the historically determinate effects of war. In the guise of civil society, however, this history is transformed and perpetuated in "a form of unspoken warfare." It is the transformative energy of war which prompts Foucault to write, elsewhere, "Beneath the forgetfulness, the illusions or the lies which make us believe in the necessities of nature or the functional exigencies of order, we must find war; war is the key which cracks the code of peace."[4]

Clausewitz considered Napoleon the "god of war," for the scale and intensity of his campaigns, and his ability to arm and motivate a nation. Clausewitz's thesis is predicated on the notion that in his day war had reached an absolute state which was made possible by the genius of Napoleon. Prior to the French revolution, war had reached a state of technical perfection which brought on inertia. The link between the political interests of the state and the monarchical form of government meant that armies were paid from the king's treasury. As war became more exclusively the business of the government, it became a more cautious affair: mercenary armies were difficult and costly to replace. War was reduced to an emphatic form of diplomacy.

With the outbreak of the French revolution all this changed. "War had again suddenly become an affair of the people and that of a people numbering thirty millions, every one of whom regarded himself as a citizen of the state." (384) After Napoleon perfected this form, national armies followed in Spain, Austria, Russia, and Prussia. The reliance of the nation on violence rather than diplomacy to extend its grasp of resources and power, the ability to mobilize a national population behind a single cause, the massive hierarchical organization of these armies, the proliferation of weapons and transportation technology so that no army had a clear technological advantage -- these are the characteristics of the Napoleonic campaigns.

Because the European economy was so geared towards war production, and because the practical knowledge of war became so proliferous, a deadlock of aggression was forming. The historical understanding of war thus required a theorization in order to continue to reproduce itself. Future wars would be written rather than simply practiced. This is the beginning of what Clausewitz will characterize at the end of his treatise as an "armed neutrality," war as a perpetual state of preparedness.

Clausewitz contributes two concepts to this theoretical revamping of military history: the division of war into the realms of tactics and strategy, and the personification of the state in the figure of the general. The division of war into tactics -- the concrete mechanics of winning battles -- and 
strategy -- the coordination of successful battles to win a war -- requires the formation of a military hierarchy. At the bottom are the troops, who represent the means to win battles, and at the top is the general, who represents the ability to convert victories to political dominance.

But the division into strategy and tactics not only requires a hierarchical division of labor, it also produces and justifies it. When warfare is conducted in the domain of friction and the result depends largely on chance, the moral strengths of an army are its most important. These come from either the talents of the general, or from what Clausewitz calls "military virtue."

The general's command is legitimized by his relationship to the metaphorics of sight. Given the ambition of the recent international campaigns, the general may not be able to make direct visual contact with either the terrain his army will cover or the army itself. He compensates for the first deficiency, according to Clausewitz, by "an act of the imagination.".(153) This is a practice, Clausewitz says, which should naturally increase "along with rank" (154) The general's illusory power of independence results from his ability to positivize the unseen: by envisioning the future state of battle.

The ranks under the general aren't permitted such acuity. Since there is, according to Clausewitz, "no particular energy and capacity of the brain required...to make a man merely what is called a true soldier," (155), their strength of will comes from being in the presence of the general. The body of the army under the general is likened in several places in the text to a huge cybernetic machine. The machine operates to a greater or lesser degree of success depending upon its ability to overcome internal resistance. "[T]his resistance," says Clausewitz

is the whole feeling of the dissolution of all physical and moral power, it is the heartrending sight of the bloody sacrifice which the Commander has to contend with in himself, and then in all others who directly or indirectly transfer to him their impressions, feelings, anxieties, and desires. As the forces in one individual after another become prostrated...the whole inertia of the mass gradually rests its weight on the Will of the Commander...in so far only as he is equal to this, he stands above the masses and continues to be their master... (145)

Where they can see the general's courage, they can identify with him, and raise themselves above their "animal nature, which shrinks from danger and knows not shame.".(145) They effect a transference, or a transcendence. Where the troops are out of reach of this vision of the general, they must depend upon military virtue for their moral support. 
In the European standing armies of the seventeenth and eighteenth centuries, military virtue was a code of professionalism. When war goes national and becomes a patriotic duty rather than a vocation, the principle of nation must substitute for the principle of class. The effect of this is to naturalize the class stratification of humanism: the qualities of reflection, perception, and imagination are what qualify the general to lead and make him worthy of emulation by the troops. Where the absence of the visual object of the battlefield gave the general his authority, it is precisely this absence of the direct visual connection between the troops and the general which justifies patriotism. "Military virtue is for the parts," says Clausewitz, "what the genius of the Commander is for the whole...In national risings, "(256) the place of military virtue as a panoptical instrument is supplied by what Clausewitz terms "natural qualities."

What is naturalized here is the concept of national empire: the command of huge geo-political expanses, the generation and exploitation of pride in a national culture or racial heritage by the general arming of a population, and the coordination of foreign and domestic policies. The classless society is produced in this text at exactly the moment that a hierarchy is internalized by those subjected to it. In the absence of the ability to embody the metaphorics of sight -- vision, perception, reflection -- the masses internalize a different sort of surveillance: patriotic duty.

The role of Clausewitz's theory of war is, finally, a reading lesson: its that activity of vision which ultimately teaches the reader to identify with the general. In a passage which effects the substitution of the author-function for the military-function, Clausewitz writes: "The events in each age must...be judged of in connection with the peculiarities of the time, and only he who, less through an anxious study of minute details than through an accurate glance at the whole can transfer himself into each particular age, is fit to understand and appreciate its Generals.".(387) The form of future war is now apparent: war becomes inscription, reading becomes conscription, and the subjects which constitute war are to become the subjects of the humanities.

Here are the final lines from Allan Bloom's The Closing of the American Mind:

This is the American moment in world history, the one for which we shall forever be judged. Just as in politics the responsibility for the fate of freedom in the world has devolved upon our regime, so the fate of philosophy in the world has devolved upon our universities, and the two are related as they have never been before. The gravity of our given task is great, and it is very much in doubt how the future will judge our stewardship.[5] 
II.

The most recent furor over the future of liberal education, variously described as the crisis in the humanities, political correctness, the tenure of radicals, or illiberal education, represents the humanities as simultaneously a battlefield and a citadel. The last paragraph from The Closing of the American Mind, clearly links American global power with philosophy -- "and the two are related as they have never been before. "The transformation from military power to philosophical power begs the question: where, in fact, are our military institutions located? The liberal arts in the United States have been formed largely on an understanding that the disciplines may reside comfortably under one roof, and that disciplinarity establishes and sustains the theater of dialogue. Contrary to the idea that these disciplines are threatened by the political battles over knowledge, we want to argue, that these disciplines are the product and the production of an ongoing war. Like crisis, war does not erupt in the institution.

Disciplines are thought of as having their own integrity and offering enrichment to one another, as naturally exclusive sets of pursuits which have in common these goals: the production of the humanist civil subject, the defenses of truth and aesthetic validity, the construction of visible and knowable objects. Disciplinarity is the need to continually define and redefine this agenda. In doing so, disciplinarity always projects as its ideal practitioner a subject of war. Interdisciplinarity is no revision of these ideals. In fact, it simply strengthens the borders between the disciplines making them appear, by noting the intersections of their discrete traditions, as if they can talk quite easily with one another. What we are concerned to show here is how an understanding of the liberal arts as a collection of sovereign, monolithic, and peaceable disciplines has resurfaced and has been mobilized, in a systematic show of force, against anti-disciplinarity. Antidisciplinarity is that project which seeks to dismantle or rethink the making and unmaking of those borders.

The past 20 years has seen a renewed interest in maintaining the sovereignty of the disciplines. The notion of "crisis in the humanities" is something we want ultimately to redirect into the status of knowledge and cognition whereby faculty are not at peace with one another, books can not be read at a disinterested distance, cultural values cannot be agreed upon, and dialogue (with all its liberal democratic connotations of free speech, choice, and "openness") is a structural impossibility. Our recognition of this 
situation as crisis, does not, as some would argue, embody the decline of western civilization or the end of meaning or even the futility of academic work. It is, rather, a coming to terms with the complex working conditions of discourse and society. A critical history of the humanities which takes this into account will show how the discipline can find the Arnoldian principles of beauty and truth behind a painting of rape or a pile of mangled bodies or in a symphony in honor of Napoleon.

It seems particularly noteworthy that the description of the crisis has recently escalated to the most blatant use of military tropes. The conservative columnist George Will wrote approximately two months after the end of the Gulf War that "In this low-visibility, high intensity war, Lynne Cheney is secretary of domestic defense. The foreign adversaries her husband, Dick, must keep at bay are less dangerous, in the long run, than the domestic forces with which she must deal. Those forces are fighting against the conservation of a common culture that is the nation's social cement."[6] When George Will uses military tropes to suggest that the situation is merely metaphorical, he is simultaneously making visible the relation of nationalism, education, and militarism and displacing those relations to a stylistic level. Will's uses the language of war to describe what he sees as an imposition of politics on the pristine space of liberal education.

Similarly, the comment of Harvey C. Mansfield, Jr., the latest nominee to the National Endowment for the Humanities advisory committee -- "I'm going to adopt a West Point approach and sound the guns against those in the Humanities who want to destroy the greatness of our intellectual past" -- is not a new articulation of battle, it merely reveals what is at the heart of the production of knowledge for the right. America is best served by its educators, it appears, not when they encourage freedom of speech and dissent, but when they reproduce the self-surveying subject. By acquiring the skills of literacy and critical thinking, which are in themselves highly rule-bound and conventional, the subject of this training is supposed to be raised above the bonds of his or her social and political condition. This is the paradox of American democracy: a society in which everyone can grow up to be president is a society in which almost no one can grow up to be president.

In the recent book, The War Against the Intellect: Episodes in the Decline of Discourses, Peter Shaw claims that we are in the midst of a war against the intellect when the heart, concerned with ethnicity, poverty, disease, gender experience, political convictions, and social status, reigns over "the capacity to reason."[7] In Shaw's narrative, victims emerge and begin suddenly to take places of privilege. As a result of this inequality standards are put into place which cannot be rationally and logically reckoned with because they are matters of the heart: Proof, reason, and logic are suspended in favor of a empathetic championing of what he calls "newly designated" "minorities or the oppressed." Shaw finds the challenges posed to "established 
reputations" as offensive as the claim that Western culture has some responsibility to the state of the rest of the world.[8]

In a shocking and reactionary leap in his own logic and proof, Shaw claims that "the war against the intellect had brought about a decline of discoursea slackening in the process of critical evaluation."[9] What Shaw considers to be the most recent crisis in the Humanites has produced an "atmosphere of intimidation" and evaluation of texts based on "guilt and recrimination." While scholars are being tried as war-criminals (so goes his rhetoric) the great works are "under assault by vandals and goths" of the new "pseudodiscipline."[10] Disciplinarity itself is thus threatened by a hybrid form of scholarship which Shaw sees as fake, disingenuous, and exclusive.

Shaw's collection of essays calls for an end to "unthinking toleration" among faculty members, intellectuals, grant-giving organizations, and the like. The rallying call of The War Against the Intellect is not only a call to preserve traditional humanist inquiry but is also an unabashed claim to preserve and defend a superior race. If the torch is to be effectively passed on, the defenders must train their children to defend. In which case their victory is dependant upon a nation whose narratives may be plural but must have the same common denominator from the fields of aesthetic, moral, emotional, and social valuation.

This, then, is the strategy of the conservative right agenda. To build an empire through the use of storytelling and tradition. Peter Shaw and George Will demonstrate how the characterization of the academy-as-war-zone displaces the sort of war that we argue can be found in disciplinarity.

Tradition, as de Certeau suggests, is a strategic practice. It is the strategy of making the temporal seem a spatial sequence of points. The strategy of basing the humanities on an unbroken trajectory is enacted by the reduction of time and movement, "to a line...that can be seized as a whole by the eye and read in a single moment...However useful this 'flattening out' may be, it transforms the temporal articulation of places into a spatial sequence of points" $[11]$ The function of disciplines is to organize the past as a space which can be surveyed entirely from the perspective of each consecutive trainee. The inclusive lists of names, dates, places, styles, and inventions are, as de Certeau says, "marks in place of acts."[12] This marking becomes the consummate disciplinary act, turning the vast disjunctive terrain of any idea's past into a linear consecution (train) of facts.

Knowledge and strategy operate together, according to de Certeau, to maintain the boundaries around the discipline, to write a field of objects which can be both objectively known and the property of the knower. "Thus 
military or scientific strategies have always been inaugurated through the constitution of their 'own' areas."[13]

Clauswitz's general is the embodiment of this subjective and possessive power/knowledge relation, who "carr[ies] in himself the whole mental apparatus of his knowledge, that anywhere and at every pulse beat he may be capable of giving the requisite decision from himself. Knowledge must, by this complete assimilation with his own mind and life, be converted into real power."[14]

The general/humanist is shown to be necessary to the building of the nation, for instance to the building of the George Will's "national fabric," in the formation of the universities and colleges in this country. The specialized and legitimate status of the humanist scholar is in itself not timeless, but comes about in this country as a legitimized discourse between 1880 and 1920. At the moment of his creation, he becomes the embodiment of, among other things, continuity, "higher civilization" based on universal ideals, a "pervasive onward and upward mood," and fluency in a specialized language which allows him the status of the keeper of the gates of tradition.[15]

Post-Civil War education reforms sought to mimic the nation in the space of the universities through departmentalization and the creation of the university president. This figure is not a specialist in all of the fields he oversees, but rather has the vision and economic strategy to connect all the disciplines in dialogue. The disciplines learned "pious tolerance," blending in with one another under the mission-statement of each president. This is the reproduction of the Nation precisely because it controls diversity and dissent and at the same time produces the "illusion of dialogue" and a false atmosphere of equivalence.[16]

The disciplinary organization of the liberal arts undergoes a significant shift in the 1920's. A survey course in Western Civilization was offered for the first time at Columbia during World War I, and was widely imitated in the years following. The "traditional" approaches to the humanities are not traditional but have only emerged out of a larger ideological conflict over global power which relies on the notion of tradition to tell its story. The need to produce cultivated, ethical, and moral civilians who would eagerly defend the hegemonic viewpoint was urgent and the Humanities curriculum could do this quickly and efficiently by arming students with an agreed upon amount of Western Culture.[17] The cold war creation (1964) of the National Endowment for the Humanities (NEH) sought to maintain precisely this agenda. 
The "crisis" in the Humanities has been addressed nationally by the former chairman William Bennett, who went on to become the Secretary of Education and the nation's "Drug Czar." He is succeeded by Lynne Cheney, wife of the Secretary of War Dick Cheney. Both Bennett and Cheney espouse "ideology-free" or "value-free" methods in the Humanities.

Cheney promotes and participates in an atmosphere which will not tolerate the curricular revisions which challenge the nature of disciplinarity through new methodologies and the study popular culture. She has been actively targeting the University of Minnesota's Humanities Department as an example of what she calls "humanities gone bad," in her reports to the President (of the US), and speeches given around the country. At the second convention of the conservative National Association of Scholars, titled "Strategies for the Nineties," Cheney likened the humanities to "storytelling" and charged that, unfortunately, some among us in the humanities do not like stories very much. Politics, for the agenda she represents, are seen as outside the ability to write the coherent history of culture. "The Humanities," says Cheney, "are about more than politics."[18]

The University of Minnesota's Department of Humanities was founded in 1945 and offered the traditional survey courses typical of the time. In 1989 the 1946 humanities curriculum was overhauled in order to promote an antidisciplinary curriculum which the department faculty felt was necessary to expose students to current academic debates. The Humanities department is the first department nationally to develop a full Cultural Studies curriculum at the undergraduate level. Evaluations by the College in 1989 ranked the Humanities department one of the college's top departments and formally identified it as being on the verge of national recognition. The department was cut in December of 1991.

Julia Davis, newly appointed Dean of the College of Liberal Arts, initiated the cut. We are not positing a direct connection between the cut and Cheney's command; nor do we wish to engage the metaphorics of war here. What we want to show ultimately is how the production of the discourse of the humanist subject, a subject whose relation to knowledge is part of a history of modern war, has enabled the unprecedented cut of a department of this kind. The explanation given is that the University does not need a Humanities department to provide the students exposure to the liberal arts discipline. What allows her to make this equation is the logic of interdisciplinarity, the same logic which emerged and organized the liberal arts in the 1920's, and the strategy of making visible a humanist field which can be easily reallocated (or un-mapped). We probably do not need to show here how disciplinarity and the dialogue between disciplines is reinforced, and the possibility of an anti-disciplinary program is short-circuited. 
Where does this put our humanist subject? Davis attempts to link her actions up with providing students a more valuable education, one which saves the University money and prepares students for "real" life - -- a life which she believes responds to the national concerns of community: "We can't afford to ignore the political realities...The fact is that if we only talk about our lofty ideals and how we can create in students the ability to lead a more examined life, we run the risk of alienating a large portion of the community. [19] "Lofty ideals," and "a more examined life," fit together here in what appears to be a strange twist because one seems distant and the other grounded. The action is meant to display an institution which responds to needs rather than creating them. The blindness here is not that "lofty ideals," are sometimes useful but that, as we have been saying, the institution has produced the student so that its needs can be met by the larger national framework. The notion that Dean Davis is serving "the community" with the cut is a way of nodding to this national framework -constituting it -- without being forced to contend with its constitution. If the humanities department is indeed forced out of existence it does not mean that there will be nothing but Clausewitzian subjects in the future -- it means that the Clausewitzian model has the most legitimated relationship to knowledge and power. The question of how to challenge this has not been the goal of this paper; but we suggest that it is anti-disciplinarity which provides the most powerful critique. Unfortunately, anti-disciplinarity is antithetical to institutionalized power.

What sort of defense is possible against this knowledge/ power machine? De Certeau suggests that consumption, or the antithesis of production, as production, is a way to take advantage of the hegemonic division of thought and work into strategy and tactics. This is to replay the tactical category of "use" as re-use; to re-use in order to refuse.

The only way to refuse the ruthless organization of the train, de Certeau says, is to go to the bathroom -- to produce refuse, and dump it on the tracks. One can expose the tireless shifting by producing shit. Until recently, one such possibility of anti-disciplinarity was housed in the University of Minnesota Humanities department.

We find ourselves caught again between strategy and tactics, between de Certeau's use of Clausewitz and Foucault's. De Certeau's conception of "making do" would have us engage in "actual linguistic combat,"[20] using our wits against the propriety ordained by grammar. But to what re-use can we put Foucault's use of Clausewitz, scattered throughout his writing? These lines from "War and the Filigree of Peace" have (dis)organized our own, because they ask us to be suspicious of any attempt to "use" tactics against themselves, especially by our wits: "War divides up the whole social body in a permanent way, placing each of us in one camp or the other. And it 
is not enough, according to the new type of discourse in question, merely to rediscover war as a principle of explanation: we are supposed to reactivate it, to make it come out of the mute and larval forms in which it is carried on unnoticed; we have to draw it into a decisive battle, for which we must prepare ourselves if we want to be the victors."[21] At the heart of strategy Foucault locates a diabolical sense of humor: in his parody of strategic logic, does he suggest that we have a responsibility to engage in struggle with the disciplines we are subject to? or that we are doomed to engage in this struggle?[22] This is the dilemma of interpretation, and, as scholars in the humanities, it is our legacy, catching us between conflict and cooperation. [23]

\section{Jenny Horne and Jonathan Kahana}

\section{University of Minnesota}

Surface Page d'Acceuil/Home Page

[1]Michel de Certeau, The Practice of Everyday Life (Berkeley: U of California P, 1984) 112.

[2]Carl von Clausewitz, On War Trans. J.J. Graham. Ed. Anatol Rappaport. (London: Penguin, 1968) 202-03.

[3]Michel Foucault, "Two Lectures." Power/Knowledge: Selected Interviews and Other Writings, 1972-1977. Trans. Colin Gordon et. al. (New York:

Pantheon, 1980) 90.

[4]Michel Foucault, "War in the Filigree of Peace", Oxford Literary Review 4:2 (1980) 16.

[5]Allan Bloom, The Closing of the American Mind, (New York: Simon and Schuster, 1987) 382.

[6]George Will,"Literary Politics" Newsweek, April 22, 1991.

[7]Peter Shaw, The War Against the Intellect, (Iowa: U of Iowa P, 1989) xi, xii.

[8]Shaw, xii.

[9]Shaw, xii. 
[10]Shaw, 167.

[11]de Certeau, 35.

[12]ibid., 35.

[13]ibid., 36.

[14]Clausewitz, 200.

[15]Lawrence Veysey, "The Plural and Organized Worlds of The Humanities" in The Organization of Knowledge in Modern America 1860-1920 . Ed. A Olesson and John Voss (Baltimore: Johns Hopkins UP, 1979) 51-106.

[16]Lawrence Veysey, The Emergence of the American University, Chicago: $\mathrm{U}$ of Chicago P, 1965),58. Veysey is worth quoting here: In theory a professor of agriculture was as respectable as a professor of Greek; therefore their purposes were entitled to equal consideration by a university president who stood over both of them. Toleration would ultimately emerge from this situation; everyone would leave everyone else alone, unless a particular jurisdictional quarrel arose. The university went several different ways at once. It crystallized into a collection of divergent minds, usually ignoring each other, commonly talking past one another, and periodically enjoying the illusion of dialogue on "safe" issues. (58)

[17]Veysey, Organization 54-55.

[18]Lynne Cheny quoted in Minnesota Daily, "National Chair Says Humanities More Than Politics" 16 November 1990.

[19]Richard Broderick, "Liberal Values" in Update: College of Liberal Arts Bulletin , University of Minnesota, March 1992, p. 9. pp. 16-17.

[20]de Certeau, 39.

[21]pp. 16-17.

[22]Aron, Raymond, Clausewitz, Philosopher of War. New York: PrenticeHall, 1985. Aaron writes in his conclusion, "For some time, how long no one can tell, humanity is condemned to more or less peaceful coexistence between peoples who more or less misunderstand one another"

[23]cf. Manuel de Landa, War in the Age of Intelligent Machines. (Cambridge, MA: Zone,1991) 83. 